\title{
Long Non-Coding RNAs in Multidrug Resistance of Glioblastoma
}

\author{
Parvaneh Mahinfar ${ }^{1}$, Behzad Baradaran ${ }^{1} \oplus$, Sadaf Davoudian ${ }^{2}$, Fatemeh Vahidian ${ }^{1}$, William Chi-Shing Cho ${ }^{3, *(1)}$ \\ and Behzad Mansoori $1,4, *$ (D) \\ 1 Immunology Research Center, Tabriz University of Medical Sciences, Tabriz 5166/15731, Iran; \\ parvaneh.mahinfar2020@gmail.com (P.M.); baradaranb@tbzmed.ac.ir (B.B.); f_vahidian1370@yahoo.com (F.V.) \\ 2 Humanitas Clinical and Research Center-IRCCS, 20089 Milan, Italy; sadaf.davudian68@gmail.com \\ 3 Department of Clinical Oncology, Queen Elizabeth Hospital, Hong Kong, China \\ 4 Department of Cancer and Inflammation Research, Institute for Molecular Medicine, \\ University of Southern Denmark, 5230 Odense, Denmark \\ * Correspondence: chocs@ha.org.hk (W.C.-S.C.); B.mansoori_lab@yahoo.com (B.M.)
}

check for updates

Citation: Mahinfar, P.; Baradaran, B.;

Davoudian, S.; Vahidian, F.; Cho, W.C.-S.; Mansoori, B. Long NonCoding RNAs in Multidrug Resistance of Glioblastoma. Genes 2021, 12, 455. https://doi.org/ $10.3390 /$ genes 12030455

Academic Editor: Robert Brosh

Received: 20 February 2021

Accepted: 19 March 2021

Published: 23 March 2021

Publisher's Note: MDPI stays neutral with regard to jurisdictional claims in published maps and institutional affiliations.

Copyright: (c) 2021 by the authors. Licensee MDPI, Basel, Switzerland. This article is an open access article distributed under the terms and conditions of the Creative Commons Attribution (CC BY) license (https:// creativecommons.org/licenses/by/ $4.0 /)$.

\begin{abstract}
Glioblastoma, also known as glioblastoma multiforme, is the most aggressive brain tumor in adults. Despite the huge advance in developing novel therapeutic strategies for patients with glioblastoma, the appearance of multidrug resistance (MDR) against the common chemotherapeutic agents, including temozolomide, is considered as one of the important causes for the failure of glioblastoma treatment. On the other hand, recent studies have demonstrated the critical roles of long non-coding RNAs (lncRNAs), particularly in the development of MDR in glioblastoma. Therefore, this article aimed to review lncRNA's contribution to the regulation of MDR and elucidate the underlying mechanisms in glioblastoma, which will open up new lines of inquiry in the treatment of glioblastoma.
\end{abstract}

Keywords: multidrug resistance; glioblastoma; lncRNAs; temozolomide

\section{Introduction}

Gliomas are identified as highly prevalent forms of brain malignancies in humans [1]. In accordance with the cellular origin of tumors, they are sub-classified into four categories including astrocytomas, oligodendrogliomas, ependymomas, and mixed tumors [2]. In addition, gliomas are also divided into four grades from the histological and genetic points of view. Low-grade gliomas are called grade I and II tumors and high-grade gliomas are considered grade III and IV [3]. Glioblastoma is known as glioblastoma multiforme (GBM) and is placed in the grade IV astrocytoma category. It is known as the most common and aggressive type of gliomas with an extensively low survival rate after diagnosis [4]. The incidence of GBM ranges from $0.59-5 / 100,000$ persons [5]. With the standard therapeutic regimen, including the maximal surgical resection, chemotherapy, and radiation, the survival values for patients is only 12-14 months [4]. In the case of lack of any therapeutic intervention, this value drops to 6 months [6].

Despite the huge efforts in understanding the underlying mechanisms in the initiation/progression of glioblastoma, its etiology is not fully understood. It is well known that there is a great degree of heterogeneity in different features of glioblastoma such as molecular, cellular, and histological characteristics [7]. Due to this heterogeneity, the tumor recurrence and development of multidrug resistance (MDR) to conventional chemotherapeutics are two common events in patients with glioblastoma [7]. MDR is defined as the capability of cancer cells to remain resistant against a broad spectrum of anti-cancer treatments [8]. Reducing the absorption of the drug following the induction of their release outside of the cells may develop the MDR mechanism [9].

Therefore, recent studies have focused on discovering the molecular mechanisms of MDR in glioblastoma and efficient strategies to reverse it. MDR is developed by alteration in a broad range of cellular events, from variation in drug efflux and metabolism to disruption of apoptosis, cell cycle, and DNA repair and dysregulation of non-coding RNAs [10-13]. At 
which, long non coding RNAs (lncRNAs) have recently been described as RNA molecules with a length of more than 200 nucleotides, which do not code into protein [14]. LncRNA naturally does not have functional open reading frames (ORFs) but it maintains the protein-coding genes feature, for instance $5^{\prime}$ cap and alternative splicing. Moreover, many of them have two or more exons and a majority of them have polyA tails (about 60\%) [15]. These long RNAs have been demonstrated to play active roles in various biological and physiological processes through controlling gene expression at three levels: the transcriptional, post-transcriptional, and epigenetic levels [16]. LncRNAs are transcribed by RNA polymerase II [17]. An accumulating number of recent studies have reported that lncRNAs are involved in the development of MDR to standard chemotherapeutics in various human malignancies including glioblastoma [18]. Therefore, in this review, we first discussed the critical function of lncRNAs in the glioblastoma, then focused on lncRNA's roles in the development of MDR in glioblastoma, and the lncRNAs potential for targeting MDR.

\section{LncRNAs: Amazing Non-Coding RNA Molecules}

LncRNAs play substantial roles in the cellular biological process by regulating the expression of various target genes, in either a negative or positive manner [19]. This is achieved by direct interference with gene promoters or modification of chromatin structures [20]. In addition, IncRNAs can interact with specific proteins, and alter their localization or their structure, and hence modulate their activity [20]. LncRNAs are precursors of small RNAs and are involved in the processing of other RNA molecules into small ones [21,22]. More importantly, recent evidence has demonstrated the presence of a sophisticated regulatory network between lncRNAs and miRNAs with critical roles in the regulation of various pathophysiological processes [22]. There are two classifications for lncRNAs according to their genomic position and origin and biological roles and functions.

\section{Genomic Position and Origin}

IncRNAs are classified into five groups in accordance with their genomic position and origin [23]. These groups are sense, antisense, bidirectional, intronic, and intergenic (Figure 1). Sense lncRNAs are RNA molecules overlapping with one or more exons of specific genes, which have transcription direction to the coding gene. Antisense lncRNAs also overlap with exons of specific coding genes with a transcription direction opposite to the corresponding gene. Bidirectional lncRNAs are located in the proximity of the proteincoding genes, opposite the DNA strand. The fourth group (intronic lncRNAs) is located in the intronic region of coding genes. Finally, the fifth group, the intergenic lncRNAs, originate from a genomic sequence between the two independent coding genes [23].

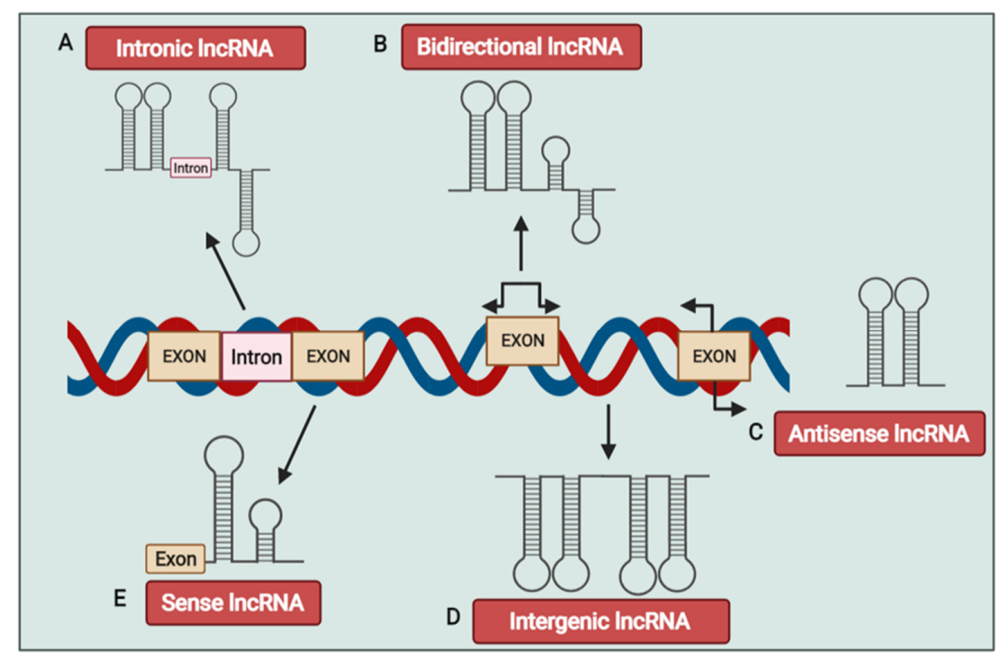

Figure 1. Overview of long non-coding RNA (lncRNA) classification. Based on the genomic position and origin, lncRNAs classified in 5 group including sense, antisense, bidirectional, intronic, and 
intergenic lncRNAs. Interonic lncRNAs are transcribed in the genomic region between two coding areas (Exons) (A). Bidirectional lncRNAs are transcribed from the opposite strand, in the opposite direction (B). Antisense lncRNAs are transcribed from the opposite strand of coding exons (C). Intergenic lncRNAs are transcribed from the intergenic regions of protein coding genes (D). Sense lncRNAs are transcribed from the sense strand of an intronic region with no overlap of exonic sequence (E).

\section{Biological Roles and Functions}

IncRNAs are classified into five groups based on their biological roles and functions in the cells, including signals, molecular decoys, molecular guides, and scaffolds. Signal lncRNAs are involved in responding to the various stimuli, in a spatiotemporal manner, so that their expressions reflect the modulation of the gene and can be a marker for major biological events (Figure 2) [24,25]. IncRNAs interact with specific effector proteins that are involved in chromatin modification or gene expression, and later, their biological functions are considered as a molecular decoy (Figure 2) [26]. lncRNAs with a molecular guide direct the ribonucleoproteins to their specific locations on chromatin by binding to them. These lncRNAs exert regulatory effects on gene expression in two manners; on neighboring genes or cis manner, or distantly located genes, trans manner [27]. The fourth group of lncRNAs is considered scaffolds that serve as main platforms for assembling the distinct proteins as a chromatin-modifying complex, hence activating or suppressing the expression of target genes (Figure 2). The last and recently identified group is called ceRNAs, which act as miRNA sponges (Figure 2) [28]. These lncRNAs bind to miRNA through their miRNA-specific binding sites and regulate the miRNA expression and function [28]. Other than miRNA sponging, there are two other hypotheses which describe how IncRNAs can be involved in the regulation of miRNAs. The first hypothesis claims that they may act as precursors of miRNAs generation and the second hypothesis proposes their role in miRNA binding alteration through the direct competition for binding sites [29]. IncRNAs are transcribed in stage-specific and cell type manners with low expression levels in the nucleus [30]. In addition, some lncRNAs are located in the cytoplasm. The subcellular localization of lncRNAs explains the approach to interact with partners and contributes to the regulation of their functional models [31,32]. Among 60,000-100,000 lncRNA genes identified within the human genome, only 200 of them are well-known [33]. Since lncRNAs show cell- and tissue-specific expression patterns, it is suggested that these RNA molecules possess important physiological and biological functions [34]. Therefore, previous studies have reported the involvement of lncRNAs in numerous phases of cell regulation including cell growth and proliferation, differentiation, cell death, genomic imprinting, epigenetic regulation, and alternative splicing, through modulating the chromatin-modifying complexes or DNA regulatory elements at transcriptional and post-transcriptional levels [35]. The versatile nature of lncRNAs is suggested as the possible reason for the diversity of their functions. The capability of RNA molecules for constructing the secondary structures leads to their interaction with multiple highly specific substrates [36]. In addition, non-coding RNAs are highly dynamic transcripts and their levels rapidly alter to ensure the efficient regulation of gene expression [36]. 


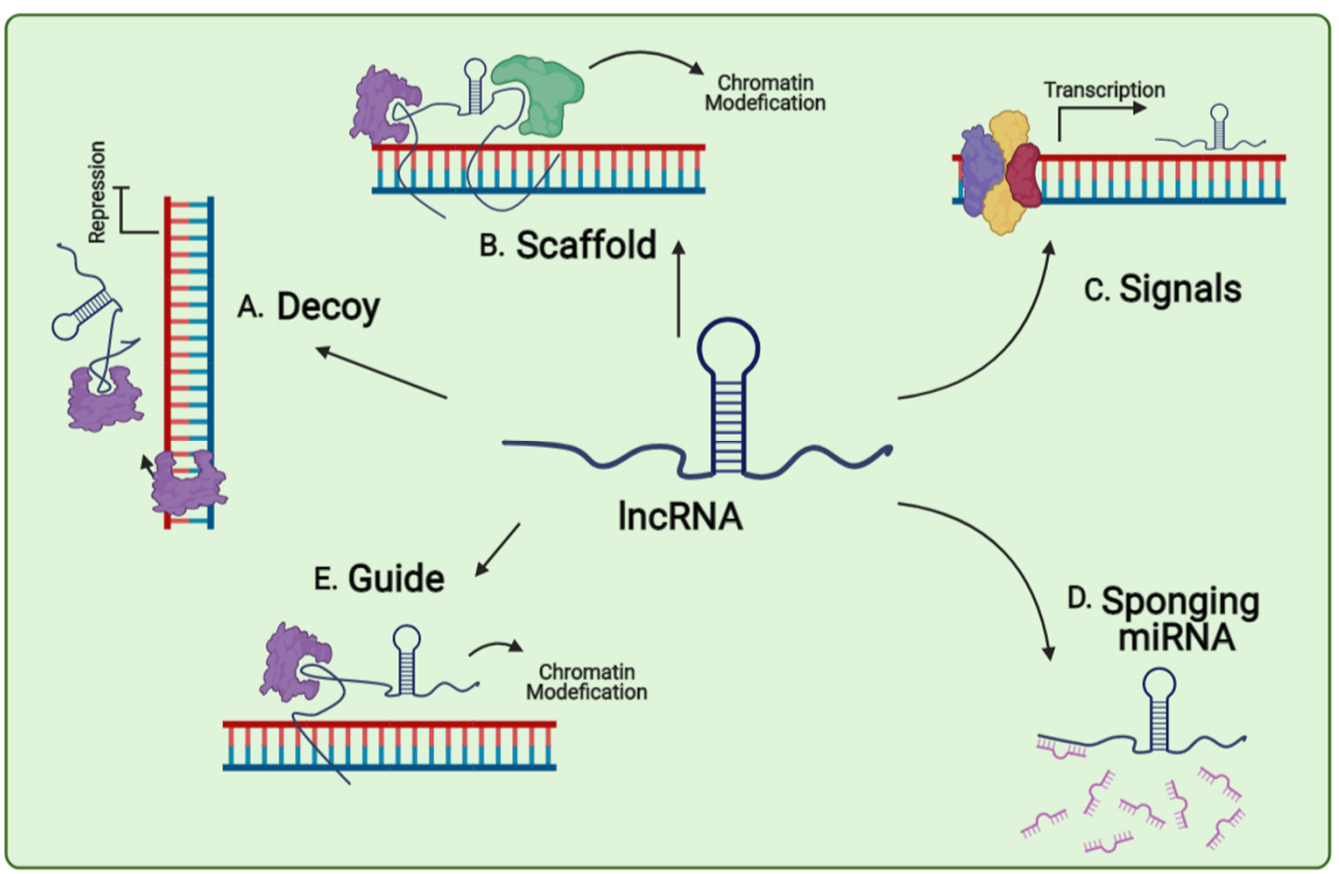

Figure 2. Overview of lncRNAs functions. Decoy lncRNAs can sponge protein factors such as transcription factors and chromatin modifiers (A). Scaffold lncRNA is involved in assembly of complex protein complexes (B). Signals lncRNAs can serve as molecular signals and can act as markers of functionally significant biological events (C). Sponging miRNA lncRNA participate in miRNA inactivation by sponging them (D). Guide lncRNAs can be molecular guides by localizing particular ribonucleoprotein complexes to specific chromatin targets (E).

\section{LncRNAs in Cancer Hallmark}

Genetic alterations and aberrant expression patterns in key genes which are related to the balance of cellular proliferation and death are considered the two main reasons for the malignant transformation of cells and cancer development. More importantly, genomewide association investigations have indicated the occurrence of a majority number (more than $80 \%$ ) of single nucleotide polymorphisms (SNPs) in non-coding regions of the whole genome, which are transcribed into lncRNAs. Therefore, these long non-coding RNA molecules are revealed to play crucial functions in tumorigenesis [21,24,37-41]. LncRNAs, as a highly heterogeneous group of RNA molecules, are involved in the regulation of gene expression through different mechanisms. LncRNA expression has been correlated to distinguished gene sets with a major impact on cell growth, cell cycle regulation, cell death, cell mobility, survival, pluripotency, and immune response, which contribute to the malignant transformation of normal cells into cancer cells. Not surprisingly, tumor cells showed an aberrant expression pattern for lncRNAs. This dysregulation in the expression levels of lncRNAs in cancer cells has a strong association with the cancer cell potential to initiate the tumor growth and metastasis, and reduce the patient survival rate in a broad range of human malignancies [21,24,37-40,42]. There are various mechanisms suggested for the regulatory role of lncRNAs in cancer. It is demonstrated that lncRNAs act as oncogenes and/or tumor suppressors in various cancers. Some important examples of oncogenic lncRNAs, which are upregulated in cancers and can trigger cancer progression, include: HOX transcript antisense RNA (HOTAIR), carboxyl-terminal binding protein-antisense (CTBPAS), antisense non-coding RNA in the INK4 locus (ANRIL), hepatocellular carcinoma up-regulated long non-coding RNA (HULC), HOXA transcript at the distal tip (HOTTIP), breast cancer anti-estrogen resistance 4 (BCAR4), H19, prostate cancer-associated transcript (PCAT)1/5/18, hepatocellular carcinoma up-regulated EZH2-associated long non-coding RNA (HEIH), metastasis associated lung adenocarcinoma transcript 1 (MALAT1), KCNQ1 opposite strand/antisense transcript 1 (KCNQ1OT1), prostate cancer gene expression 
marker 1 (PCGEM1), long stress-induced non-coding transcripts 5 (LSINCT5), urothelial cancer-associated 1 (UCA1), X-inactive specific transcript (XIST), SWI/SNF complex antagonist associated with prostate cancer 1 (SCHLAP1), taurine upregulated gene 1 (TUG1), and human plasmacytoma variant translocation 1 (PVT1). Tumor suppressor lncRNAs, which are downregulated in cancer cells, and their decreased expression levels lead to malignant transformation, include: GAS5, BGL3, TERRA, DILC, MEG3, DLEU1/2, PTENP1, and NBAT-1 $[21,42,43]$. The numbers of lncRNAs in the list of oncogenic and tumor suppressor lncRNAs are increasing every year by identifying the novel lncRNAs through profound evaluations and novel techniques, which highlight the undeniable importance of these RNAs in tumorigenesis and cancer therapy.

\section{Expression Profile of LncRNA in Glioma and Glioblastoma}

Due to the importance of lncRNAs in the gene regulation and critical involvement of various lncRNAs in the pathogenesis of a broad range of human malignancies, an increasing number of recent studies have examined the expression pattern of lncRNAs in gliomas and glioblastoma. For example, in a study by Han et al. [44], authors compared the expression profiles of lncRNA and mRNA in normal brain tissues and glioblastoma. Data revealed 654 up-regulated and 654 down-regulated lncRNAs in glioblastoma brain tissues. In addition, 104 matched lncRNA-mRNA pairs were found for 91 differentially expressed lncRNAs and 84 differentially expressed genes [44]. In another study by Zhang et al. [45], data showed that 129 lncRNAs had differentiated expression levels in glioma and nontumor brain tissues of 268 clinical specimens. More importantly, they observed a strong association between the expression levels of particular lncRNAs and different histological subtypes and malignancy grades [45]. Murat et al. reported 37 up-regulated and 44 downregulated lncRNAs in glioma [46,47]. Grzmil et al. evaluated 147 lncRNAs with unique expression levels in 30 glioma samples, as compared with normal brain tissues [47,48]. Li et al. described 398 lncRNAs with distinctive expression levels in glioblastoma and normal brain tissues [49]. Various studies have demonstrated a remarkable correlation between lncRNAs expression levels and glioma malignancy grade [45,50]. Therefore, disruption in the expression levels of lncRNA has a pivotal function in gliomagenesis, and many studies have examined various lncRNAs roles in different aspects of glioblastoma biology such as cell proliferation, apoptosis, angiogenesis, and metastasis. These studies are summarized in Table 1.

In order to evaluate the genetic profile in tumor tissue, extraction of the tumor is invasive, expensive, and risky for the patients. On the other hand, a small and localized biopsy from tumor tissues might not show a full capture of intratumoral heterogeneity. Therefore, in recent years liquid biopsy has attracted oncologists' attention as a promising source of biomarkers for diagnostic and prognostic purposes. The biological analytes such as circulating tumor cells (CTCs), circulating cell-free tumor RNA, and tumor-derived exosomes contain circulating lncRNA are found in body fluids such as a serum, CNS (central nervous system) fluid, etc. [51]. Tan et al. showed that HOTAIR expression in serum exosomes and exosome-depleted supernatant of glioblastoma patients was significantly higher than normal control [52]. In another study, Shen et al. measured the six known oncogenic lncRNAs, CRNDE, GAS5, H19, HOTAIR, MALAT1, and TUG1, in serum samples of 106 glioblastoma patients. Among these six lncRNAs, HOTAIR and GAS5 increased expression could serve as reciprocal prognostic predictors of patient's survival and disease progression [53]. These findings support that evaluating the lncRNA could help to accelerate the diagnosis and prognosis of glioblastoma patients. 
Table 1. LncRNA status in glioma and glioblastoma.

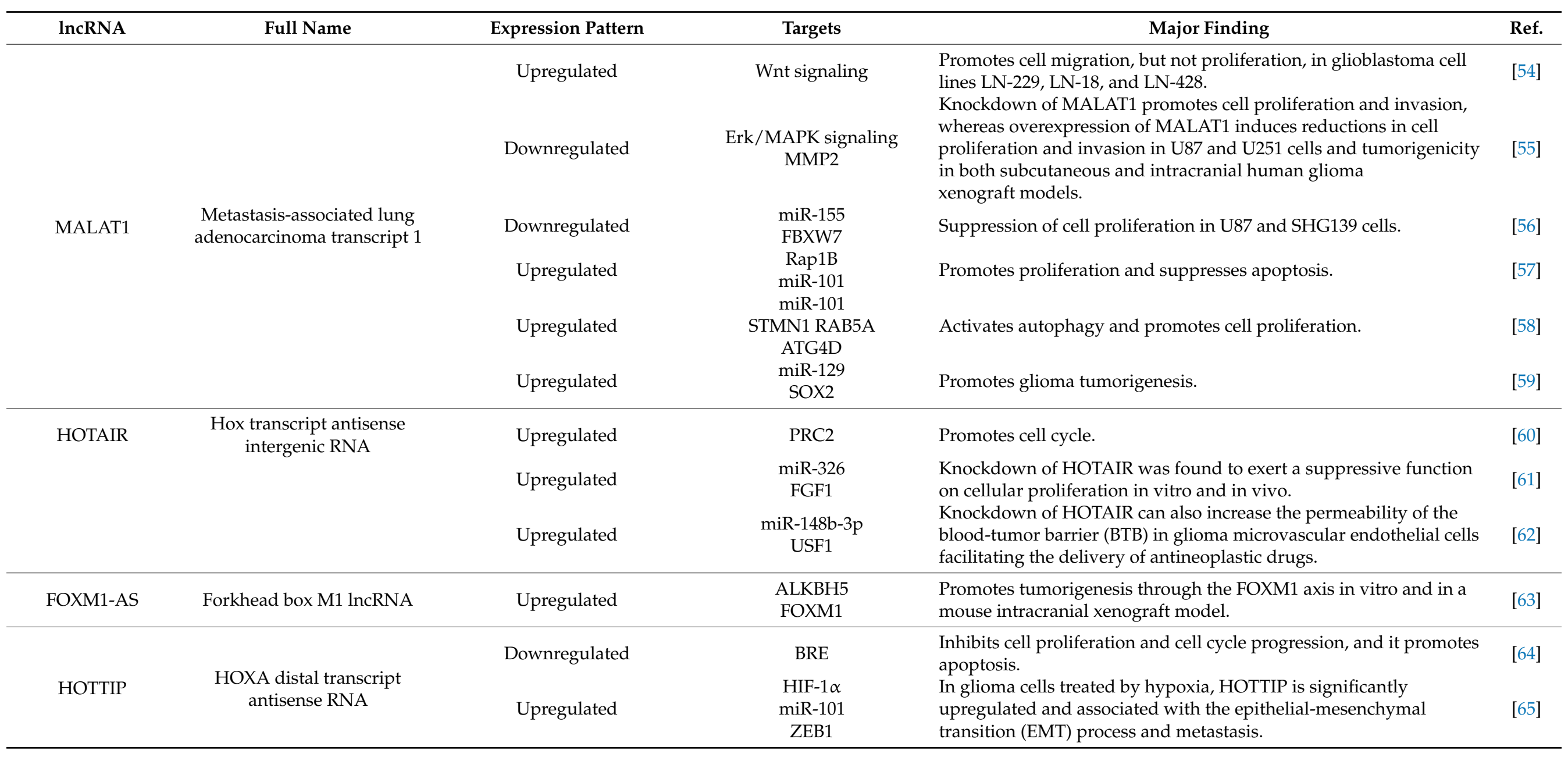


Table 1. Cont.

\begin{tabular}{|c|c|c|c|c|c|}
\hline lncRNA & Full Name & Expression Pattern & Targets & Major Finding & Ref \\
\hline \multirow{3}{*}{ HOXA11-AS } & \multirow{3}{*}{ Homeobox A11-AS } & Upregulated & HOXA & $\begin{array}{l}\text { Promotes cell proliferation by the regulation of cell cycle progression } \\
\text { in vitro and in vivo. }\end{array}$ & [66] \\
\hline & & Upregulated & miR-140-5p & Promotes the glioma tumorigenesis. & {$[67]$} \\
\hline & & Upregulated & miR-124-3p & Promotes malignant progression of glioma. & [69] \\
\hline ECONEXIN & LINC00461 & Downregulated & $\begin{array}{c}\text { miR-411-5p } \\
\text { TOP2A }\end{array}$ & Decreased cell proliferation. & {$[70]$} \\
\hline \multirow{2}{*}{ GAS5 } & \multirow{2}{*}{ Growth Arrest-Specific 5} & Downregulated & $\begin{array}{l}\text { Bm } \\
\text { Plexin C1 } \\
\text { miR-222 }\end{array}$ & $\begin{array}{l}\text { Inhibits cell proliferation. } \\
\text { Gas5 knockdown suppresses glioma growth and prolongs the } \\
\text { survival of tumor-bearing nude mice in vivo. }\end{array}$ & {$[71]$} \\
\hline & & Downregulated & $\begin{array}{l}\text { miR-196a-5p } \\
\text { FOXO1 }\end{array}$ & Inhibits glioma cell proliferation, migration, and invasion. & {$[72]$} \\
\hline \multirow{6}{*}{ H19 } & \multirow{6}{*}{-} & Upregulated & $\begin{array}{c}- \\
\mathrm{CD} 133\end{array}$ & Promotes invasion, angiogenesis, and stemness of glioblastoma cells. & [73] \\
\hline & & Upregulated & $\begin{array}{l}\text { NANOG } \\
\text { Oct4 } \\
\text { Sox2 }\end{array}$ & Increased cellular proliferation and suppressed apoptosis. & [74] \\
\hline & & Upregulated & $\begin{array}{l}\text { miR-675 } \\
\text { CDK6 } \\
\text { Cadherin }\end{array}$ & Promote glioma cell invasion. & $\begin{array}{l}{[61} \\
75]\end{array}$ \\
\hline & & Upregulated & $\operatorname{miR}-29 a$ & $\begin{array}{l}\text { Regulates glioma angiogenesis and the biological behavior of } \\
\text { glioma-associated endothelial cells. }\end{array}$ & [76] \\
\hline & & Upregulated & $\begin{array}{l}\operatorname{miR}-140 \\
\text { iASPP }\end{array}$ & Modulates glioma growth. & [77] \\
\hline & & Upregulated & $\operatorname{miR}-152$ & Promotes proliferation and invasion in human glioma cells. & [78] \\
\hline \multirow{4}{*}{ XIST } & \multirow{4}{*}{ X-inactive specific transcript } & Upregulated & $\operatorname{miR}-152$ & $\begin{array}{l}\text { Knockdown exerts tumor-suppressive functions in human } \\
\text { glioblastoma stem cells. }\end{array}$ & [79] \\
\hline & & Upregulated & miR-137 & $\begin{array}{l}\text { Knockdown of long non-coding RNA XIST increases blood-tumor } \\
\text { barrier permeability and inhibits glioma angiogenesis. }\end{array}$ & [67] \\
\hline & & Upregulated & miR-137 & Exerts oncogenic functions. & {$[80]$} \\
\hline & & Upregulated & $\operatorname{miR}-429$ & Promotes glioma tumorigenicity and angiogenesis. & [81] \\
\hline
\end{tabular}


Table 1. Cont.

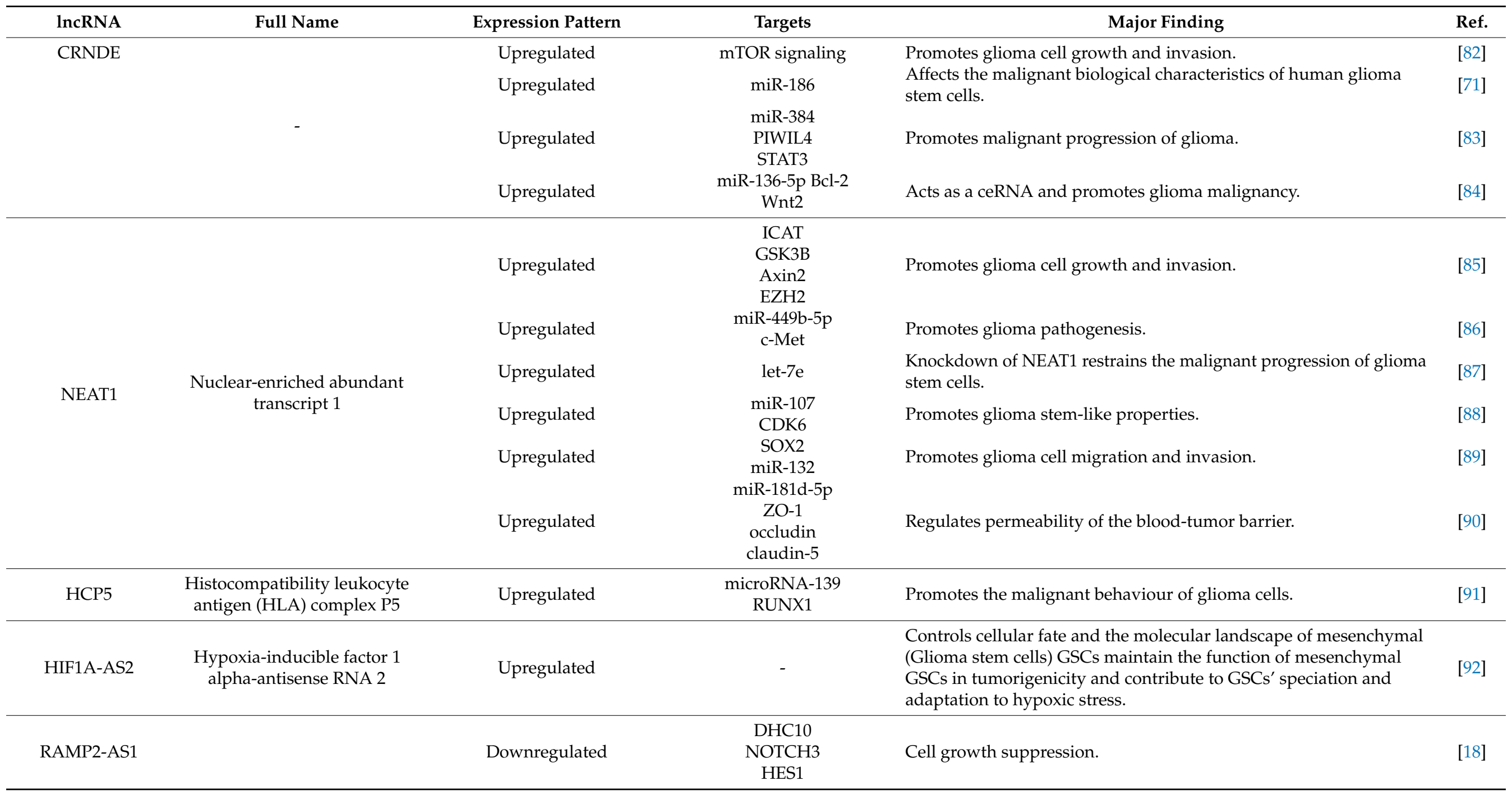


Table 1. Cont

\begin{tabular}{|c|c|c|c|c|c|}
\hline lncRNA & Full Name & Expression Pattern & Targets & Major Finding & Ref. \\
\hline linc-POU3F3 & $\begin{array}{l}\text { Long intergenic noncoding } \\
\text { RNA POU3F3 }\end{array}$ & Upregulated & POU3F3 & Promotes cell viability and proliferation. & [93] \\
\hline CASC2 & $\begin{array}{l}\text { Cancer susceptibility } \\
\text { candidate } 2\end{array}$ & Downregulated & $\operatorname{miR}-21$ & $\begin{array}{l}\text { Inhibition of glioma growth, migration, and invasion and promotion } \\
\text { of cell apoptosis. }\end{array}$ & [94] \\
\hline HMMR-AS1 & - & Upregulated & c-Myc & Promotes cell migration, invasion, and mesenchymal phenotypes. & [95] \\
\hline MEG3 & Maternally expressed gene 3 & Downregulated & $\begin{array}{l}\text { miR-96-5p } \\
\text { MTSS1 }\end{array}$ & Suppresses the growth of glioma cells. & [96] \\
\hline FLVCR1-AS1 & $\begin{array}{c}\text { Feline leukemia virus } \\
\text { subgroup C cellular Receptor } \\
1 \text { Antisense RNA } 1\end{array}$ & Upregulated & miR-30b-3p & Promotes glioma cell proliferation and invasion. & [97] \\
\hline MIR22HG & MIR22 host gene & Upregulated & Wnt $/ \beta$-catenin signalling & Increase cell proliferation, invasion, and in vivo tumor growth. & [98] \\
\hline linc00645 & $\begin{array}{l}\text { Long intergenic non-protein } \\
\text { coding RNA } 645\end{array}$ & Upregulated & miR-205-3p & $\begin{array}{l}\text { Modulates (Transforming growth factor beta) TGF- } \beta \text {-induced } \\
\text { glioma cell migration and invasion. }\end{array}$ & [99] \\
\hline
\end{tabular}




\section{Drug Resistance in Glioblastoma}

Similar to other cancer types, the development of MDR against conventional chemotherapeutics is one of the most important burdens against the complete and successful treatment of glioblastoma, as well as tumor recurrence following the complement of therapy regimen. Various mechanisms have been identified and studied for the development of MDR in cancer cells, among them, the upregulation of drug transporters, alteration in drug metabolisms, apoptosis suppression, aberrant expression of cell cycle checkpoints, dysregulation of DNA repair machinery, epithelial-to-mesenchymal transition (EMT) cancer stem cells, and the disruption to miRNA and lncRNA expression pattern are considered important ones (Figure 3). Temozolomide is the main chemotherapeutic agent with high efficiency in killing glioblastoma cells. It is reported that temozolomide chemotherapy can increase the patient survival by 2.5 months. However, the main challenge of temozolomide usage is, evolving a "hypermutator" phenotype in glioblastoma cells [100]. Temozolomide mainly leads to mutations in retinoblastoma (RB) and AKT/mammalian target of rapamycin (mTOR) signaling, which plays a critical role in glioblastoma tumor growth and metastasis [101]. Following entrance to the blood circulation, temozolomide undergoes a spontaneous conversion to 5-(3-Methyl-1-triazeno) imidazole-4-carboxamide. This active form of temozolomide is then broken down and generates the methyl diazonium cation. DNA methylation at adenines and guanines, which are mediated by methyl diazonium cation, causes the irreparable DNA damage and cell death [102]. Overexpression of $\mathrm{O}^{6}$-methyl-guanine-DNA methyltransferase (MGMT) is considered one of the main mechanisms for the development of MDR against temozolomide. This enzyme catalyzes a reaction, resulting in the removal of the methyl group from the $\mathrm{O}^{6}$ of guanine. Methylation in the MGMT promoter, which leads to its downregulation was shown to increase the temozolomide efficacy and prolong the patient survival [103]. It was reported that NEAT1 regulates MGMT in temozolomide resistance [104], NEAT1 was enhanced in TMZ-resistant GBM cells. The presence of temozolomide-resistant glioblastoma cancer stem cells is another substantial factor that contributes to temozolomide MDR [105]. Nevertheless, an accumulating number of recent studies have demonstrated that lncRNAs also mainly contribute to temozolomide MDR, which will be discussed further in the following section.

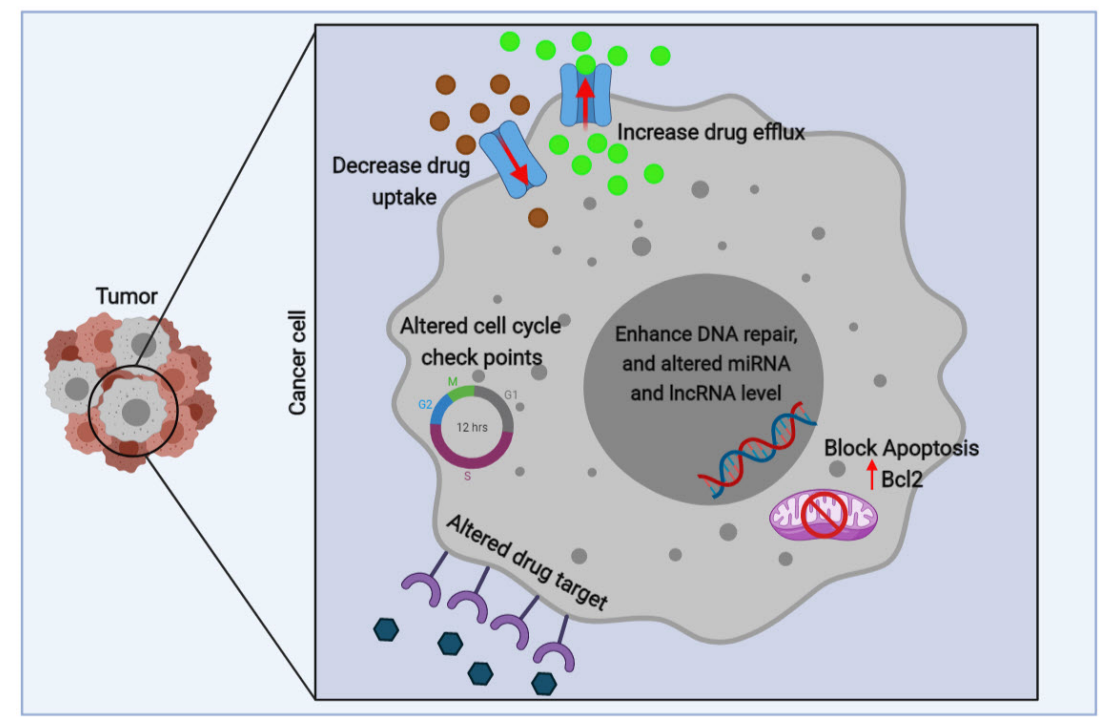

Figure 3. A scheme of the mechanisms involved in multidrug resistance in tumor cells. The mechanisms involved in multidrug resistance (MDR) overexpression include 1. An increase in ATP-binding cassette $(\mathrm{ABC})$ transporters which increases drug efflux, which reduces intracellular drug concentration. 2. Reducing drug uptake by influx transporters. 3. Blocking apoptotic signaling pathways and increase anti-apoptotic (B-cell lymphoma 2) Bcl2. 4. Enhancing DNA repair and increasing adaptability by miRNA and lncRNA regulation. 5. Mutations in drug targets. 6. Aberrant expression of cell cycle checkpoints. 


\section{LncRNAs in Glioblastoma Drug Resistance}

Various studies have investigated the involvement of multiple lncRNAs in the development of MDR or the efficacy of targeting lncRNAs in reversing MDR in glioblastoma. Evaluating the expression pattern of various lncRNAs in temozolomide-resistant glioblastoma tissues revealed that 299 lncRNAs have aberrant expression patterns in glioblastoma tissues in comparison to the normal tissues [106]. In another study, 22 lncRNAs were found with high expression in reversing MDR in glioblastoma [107]. MALAT-1 and H19 are well-studied lncRNAs in developing temozolomide MDR in glioblastoma. Herein, we list some well-known lncRNAs in temozolomide-resistance and their mechanisms of action in glioblastoma (Table 2).

Table 2. lncRNAs in drug resistance of glioblastoma.

\begin{tabular}{|c|c|c|c|c|}
\hline lncRNAs & $\begin{array}{l}\text { Expression Pattern } \\
\text { in Glioblastoma }\end{array}$ & Roles in Drug Resistance & Mechanism of Action & Ref. \\
\hline MALAT1 & Upregulated & $\begin{array}{l}\text { Temozolomide treatment-induced lncRNA } \\
\text { MALAT1. MALAT1 was a target for } \\
\text { chemosensitization of glioblastoma. }\end{array}$ & It was dependent on NF- $\mathrm{NB}$ and p53. & {$[108]$} \\
\hline MALAT1 & Upregulated & $\begin{array}{l}\text { MALAT-1 was upregulated in } \\
\text { temozolomide-resistant glioblastoma } \\
\text { patients' tissues. }\end{array}$ & $\begin{array}{l}\text { MALAT-1 inhibited miR-203 expression, hence } \\
\text { leading to MDR development. }\end{array}$ & [108] \\
\hline MALAT1 & Upregulated & $\begin{array}{l}\text { siRNA mediated silencing of MALAT-1 in } \\
\text { temozolomide-resistant cells reversed MDR. }\end{array}$ & $\begin{array}{l}\text { Downregulating MALAT-1 resulted in the } \\
\text { significant inhibition of the expression levels of } \\
\text { major drug transporters and modulation } \\
\text { of EMT. }\end{array}$ & {$[109]$} \\
\hline MALAT1 & Upregulated & $\begin{array}{l}\text { MALAT1 overcame the temozolomide-MDR } \\
\text { in cells. }\end{array}$ & $\begin{array}{l}\text { MALAT-1 knockdown resulted in the } \\
\text { upregulation of miR-101 and downregulation } \\
\text { of glycogen synthase kinase. }\end{array}$ & {$[110]$} \\
\hline MALAT1 & Upregulated & $\begin{array}{l}\text { The silencing of MALAT-1 increased the } \\
\text { sensitivity of glioblastoma cells to temozolomide. }\end{array}$ & $\begin{array}{l}\text { siRNA significantly decreased the growth, } \\
\text { motility, and stemness of glioblastoma cells. }\end{array}$ & {$[111]$} \\
\hline H19 & Upregulated & $\begin{array}{l}\text { H19 downregulation resulted in significant } \\
\text { reversing of MDR in resistant cells. }\end{array}$ & $\begin{array}{l}\text { H19 downregulation inhibits the expression } \\
\text { of EMT markers and suppresses } \\
\text { Wnt/ } \beta \text {-catenin signaling. }\end{array}$ & {$[112]$} \\
\hline H19 & Upregulated & $\begin{array}{l}\text { H19 was upregulated in temozolomide-resistant } \\
\text { glioblastoma cells. }\end{array}$ & $\begin{array}{l}\text { Downregulating H19 significantly suppresses } \\
\text { the expression levels of major drug transporters. }\end{array}$ & {$[113]$} \\
\hline H19 & Upregulated & H19 was overexpressed in resistant cells. & $\begin{array}{l}\text { Activation of the NF- } \mathrm{B} \text { B signaling pathway } \\
\text { was a mechanism for H19-mediated MDR } \\
\text { in glioblastoma. }\end{array}$ & {$[114]$} \\
\hline SNHG12 & Upregulated & $\begin{array}{l}\text { SNHG12 promoted the development of } \\
\text { temozolomide resistance in glioblastoma cells. } \\
\text { SNHG12 knockdown led to chemosensitization } \\
\text { in resistant cells. }\end{array}$ & $\begin{array}{l}\text { SNHG12 acted as a sponge for miR-129-5p. } \\
\text { It increased the expression levels of MAPK1 } \\
\text { and E2F7, led to upregulation of MAPK1 and } \\
\text { E2F7, hence promoted cell proliferation and } \\
\text { suppressing apoptosis. }\end{array}$ & [115] \\
\hline SBF2-AS1 & Upregulated & $\begin{array}{l}\text { SBF2-AS1 enhanced temozolomide-MDR in } \\
\text { glioblastoma cells. }\end{array}$ & $\begin{array}{l}\text { It increased DNA repair capacity. SBF2-AS1 } \\
\text { serves as a ceRNA for miR-151a-3p. }\end{array}$ & {$[116]$} \\
\hline LINC00461 & Upregulated & $\begin{array}{l}\text { It promoted cell proliferation, migration, } \\
\text { invasion, in glioblastoma, as well as } \\
\text { temozolomide resistance. }\end{array}$ & LINC00461 was a ceRNA for miR-216a. & [117] \\
\hline CCAT2 & Upregulated & $\begin{array}{l}\text { It promoted cell proliferation and invasion and } \\
\text { developed MDR against temozolomide in } \\
\text { glioblastoma cells. }\end{array}$ & Sponged miR-424. & [118] \\
\hline XIST & Upregulated & $\begin{array}{l}\text { It promoted cell proliferation and invasion and } \\
\text { developed MDR against temozolomide in } \\
\text { glioblastoma cells. }\end{array}$ & Targeted miR-29c. & {$[119]$} \\
\hline NCK1-AS1 & Upregulated & $\begin{array}{l}\text { It promoted cell proliferation and invasion and } \\
\text { developed MDR against temozolomide in } \\
\text { glioblastoma cells. }\end{array}$ & Targeted miR-137. & {$[120]$} \\
\hline
\end{tabular}


Table 2. Cont.

\begin{tabular}{|c|c|c|c|c|}
\hline lncRNAs & $\begin{array}{l}\text { Expression Pattern } \\
\text { in Glioblastoma }\end{array}$ & Roles in Drug Resistance & Mechanism of Action & Ref. \\
\hline SNHG15 & Upregulated & $\begin{array}{l}\text { It promoted cell proliferation and invasion and } \\
\text { developed MDR against temozolomide in } \\
\text { glioblastoma cells. }\end{array}$ & Targeted miR-627. & [106] \\
\hline DLEU2 & Upregulated & $\begin{array}{l}\text { It promoted cell proliferation and invasion and } \\
\text { developed MDR against temozolomide in } \\
\text { glioblastoma cells. }\end{array}$ & Targeted miR-186-5p. & [121] \\
\hline FOXD2 & Upregulated & $\begin{array}{l}\text { It promoted cell proliferation and invasion and } \\
\text { developed MDR against temozolomide in } \\
\text { glioblastoma cells. }\end{array}$ & Sponged miR-98-5p. & [122] \\
\hline LINC01198 & Upregulated & It promoted drug resistance in glioblastoma cells. & $\begin{array}{l}\text { Upregulated NEDD4-1 and } \\
\text { downregulated PTEN. }\end{array}$ & [123] \\
\hline MIR155HG & Upregulated & MIR155HG-induced temozolomide resistance. & $\begin{array}{l}\text { Targeted and activated the } \\
\text { Wnt/ } \beta \text {-catenin pathway. }\end{array}$ & [124] \\
\hline SOX2OT & Upregulated & $\begin{array}{l}\text { SOX2OT is involved in the development of MDR } \\
\text { against temozolomide in glioblastoma cells. }\end{array}$ & $\begin{array}{l}\text { Upregulated SOX2 expression, which activated } \\
\text { the Wnt5a/ } \beta \text {-catenin signaling pathway. }\end{array}$ & [125] \\
\hline EPIC1 & Upregulated & $\begin{array}{l}\text { EPIC1 plays a critical role in temozolomide } \\
\text { resistance. }\end{array}$ & It targeted Cdc20. & [16] \\
\hline HOTAIR & Downregulated & $\begin{array}{l}\text { It had an inhibitory role in developing MDR } \\
\text { against temozolomide. }\end{array}$ & $\begin{array}{l}\text { Increased expression levels of Hexokinase } 2 \text { by } \\
\text { targeting miR-125. }\end{array}$ & [126] \\
\hline AC003092.1 & Downregulated & $\begin{array}{l}\text { Overexpression of lncRNA AC } 003092.1 \text { overcame } \\
\text { temozolomide resistance. }\end{array}$ & Modulated miR-195/TFPI-2 signaling. & [127] \\
\hline TUSC7 & Downregulated & TUSC7 is inhibited temozolomide resistance. & Targeted miR-10a in glioblastoma cells. & [128] \\
\hline
\end{tabular}

MALAT-1, also known as nuclear-enriched abundant transcript 2 (NEAT-2), is one of the oncogenic lncRNAs with high expression level in glioblastoma tissues [129]. Its importance in temozolomide-resistance is highly addressed by various studies showing the aberrant expression levels of this lncRNA in resistant glioblastoma cells. Voce et al. [130] showed temozolomide treatment-induced lncRNA MALAT1 in an NF- $\mathrm{kB}$ and p53 co-dependent manner in glioblastoma cells, which supported MALAT1 as a target for chemosensitization of glioblastoma [130]. In a study by Chen et al. [108], the upregulation of MALAT- 1 was demonstrated in temozolomide-resistant glioblastoma patients' tissues. Temozolomide-resistant U251 and U87 cells also showed a similar pattern. Investigating the underlying mechanism has revealed that MALAT- 1 inhibited miR-203 expression, and hence led to MDR development [108] (Figure 4). Li et al. [109] showed that siRNA-mediated silencing of MALAT-1 in temozolomide-resistant U251 and U87 cells resulted in reversing MDR in these cells. It was found that downregulating MALAT-1 results in significant inhibition of major drug transporters expression levels, such as multidrug resistance protein 1 (MDR1) and multidrug resistance-associated protein 5 (MRP5), as well as modulation of EMT through targeting E-box-binding homeobox 1 (ZEB1), E-cadherin, and zonula occludens-1 (ZO-1) [109]. In another study, it was reported that MALAT-1 knockdown resulted in the upregulation of miR-101 and downregulation of glycogen synthase kinase (GSK)-3 $\beta$ in resistant glioblastoma cells, hence overcoming the temozolomide-MDR in the cells (Figure 4) [110]. Kim et al. indicated that attenuation of MALAT-1 by siRNA significantly decreased the growth, motility, and stemness of glioblastoma cells. Moreover, silencing of MALAT-1 increased the sensitivity of glioblastoma cells to temozolomide [111].

H19 is another oncogenic IncRNA which is commonly overexpressed in glioblastoma tissues and cells [131]. H19 was highly upregulated in temozolomide-resistant U251 and M059J glioblastoma cells. H19 downregulation resulted in notable MDR reversal in resistant cells through inhibiting the expression of EMT markers and suppressing Wnt/ $\beta$-catenin signaling [112]. Jiang et al. reported the presence of three distinct variants for H19 [113]. In temozolomide-resistant glioblastoma tissues, the expression levels of variant 1 were higher in comparison to the other two variants. The possible underlying mechanisms 
for H19-mediated MDR in glioblastoma are the overexpression of MDR, MRP, and ATPbinding cassette superfamily G member 2 (ABCG2) [113]. Activation of the NF- $\mathrm{kB}$ signaling pathway is considered as another mechanism for H19-mediated MDR in glioblastoma (Figure 4) [114].

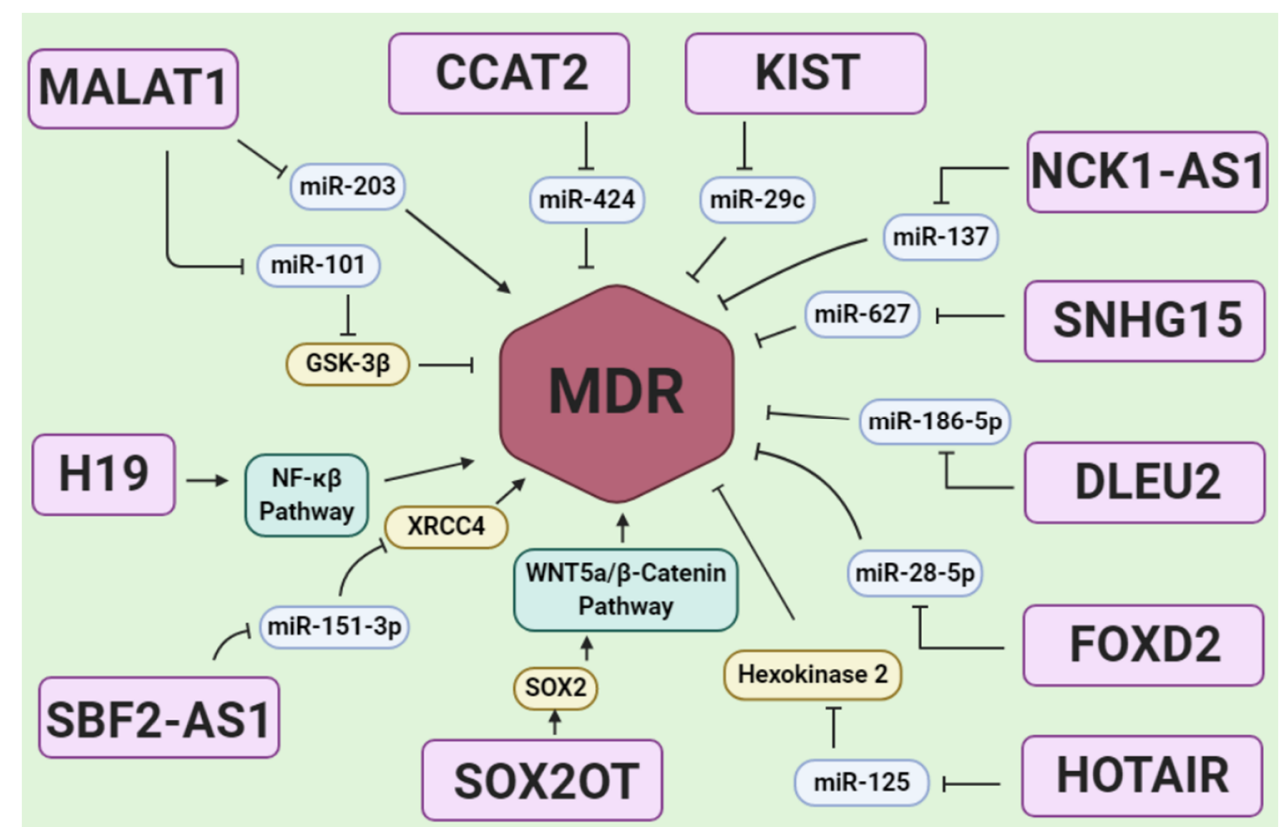

Figure 4. A scheme of lncRNAs in glioblastoma drug resistance via regulating MDR. Most of the lncRNA regulation on MDR is mediated by miRNA sponging in glioblastoma drug resistance. miRNA sponging causes MDR activation or MDR inhibition, and they may regulate via a miRNA direct sponge effect on MDR or sponging the miRNA, which is involved in targeting genes related to MDR regulation such as Sox2, XRCC4, Hexokinase 2, and GSK-3 $\beta$. In addition, some lncRNAs including H19 and SOX2OT could activate signals such as NF-kB and WNT5a/ $\beta$-Catenin which can activate MDR.

Small nucleolar RNA host gene 12 (SNHG12) is an oncogenic lncRNA, which is aberrantly expressed in temozolomide-resistant glioblastoma cells and tissues. Lu et al. [115] reported that SNHG12 acts as a sponge for miR-129-5p, therefore leading to elevated expression of MAPK1 and E2F7, which in consequence promotes cell proliferation, suppresses cell apoptosis, and enhances the development of temozolomide resistance in glioblastoma cells. In addition, SNHG12 knockdown led to chemosensitization in resistant cells [115]. Another overexpressed lncRNA in temozolomide-resistant glioblastoma cells is SBF2 antisense RNA 1 (SBF2-AS1) (Figure 4) [116]. It was demonstrated that SBF2-AS1 serves as a ceRNA for miR-151a-3p and by targeting X-ray repairs the cross-complementing 4 (XRCC4), which is a key component of DNA repair machinery, increased the glioblastoma cells' ability to repair the DNA damages. For this reason, SBF2-AS1 enhanced the temozolomide-MDR in glioblastoma cells through increasing the DNA repair capacity [116]. IncRNA LINC00461 was also indicated as ceRNA for miR-216a [117]. This oncogenic lncRNA promoted cell proliferation, migration, and invasion in glioblastoma, as well as temozolomide resistance through targeting the miR-216a and aquaporin 4 pathway. Thus, silencing LINC00461 led to remarkable chemosensitization in glioblastoma cells [117]. CCAT2 by sponging miR-424 [118], XIST by targeting miR-29c [119], NCK1-AS1 by targeting miR-137 [120], SNHG15 by targeting miR-627 [106], DLEU2 by targeting miR-186-5p [121], and FOXD2 by sponging miR-98-5p [122] play a major role in the promoting cell proliferation and invasion and developing MDR against temozolomide in glioblastoma cells (Figure 4).

In addition to miRNAs, IncRNAs were reported to increase the chemoresistance in glioblastoma cells by targeting various proteins. ADAM metallopeptidase throm- 
bospondin type 1 motif 9 antisense RNA 2 (ADAMTS9-AS2), with an upregulated pattern in temozolomide-resistant glioblastoma cells, was reported to promote the resistant phenotype. Upregulating the fused in sarcoma (FUS), which is an RNA-binding protein associated with ADAMTS9-AS2 and E3 ubiquitin-protein ligase MDM2 [132]. LINC01198 promoted the drug resistance in glioblastoma cells through upregulating neural precursor cells and developmentally downregulated 4, E3 ubiquitin-protein ligase (NEDD4-1) and phosphatase and tensin homolog (PTEN) [123]. NEAT1 and FoxD2-AS1 hypermethylated of the promoter region of MGMT, hence mediate temozolomide resistance $[133,134]$. LncRNA MIR155HG induced temozolomide resistance in glioma cells through targeting and activating the Wnt/ $\beta$-catenin pathway [124]. LncRNA SOX2OT was involved in the development of MDR against temozolomide in glioblastoma cells through upregulating SOX2 expression, which activated the Wnt5a/ $\beta$-catenin signaling pathway (Figure 4) [125]. EPIC1 lncRNA plays a critical role in the temozolomide resistance by targeting Cdc20 [16].

In addition to various $\ln$ RNAs with MDR promoting roles, some lncRNAs inhibit MDR in glioblastoma. For example, Zhang et al. [126] described the critical role of the inhibitory function of HOTAIR lncRNA in developing MDR against temozolomide in glioblastoma cells. Resistant glioblastoma cells showed decreased expression levels of HOTAIR. Overexpressing this lncRNA led to elevated expression levels of Hexokinase 2 by targeting miR-125, hence impeding the cell growth and enhancing the temozolomideinduced apoptosis (Figure 4) [126]. Xu et al. [127] showed that overexpression of lncRNA AC003092.1 overcame temozolomide resistance by modulation of miR-195/TFPI- 2 signaling in glioblastoma. TUSC7 is another lncRNA that inhibited temozolomide resistance by targeting miR-10a in glioblastoma cells [128].

\section{Conclusions}

The present review has demonstrated the major involvement of various lncRNAs in the development of MDR in glioblastoma. Targeting MDR transporters, modulating apoptosis, targeting DNA repair machinery, controlling cancer stem cells, regulating EMT, and crosstalk with major pro-oncogenic signaling pathways are among the most important mechanisms in miRNAs-mediated MDR in glioblastoma. Therefore, targeting lncRNAs seem to be an appropriate strategy for combating treatment obstacles in glioblastoma.

On the other hand, there is still limited knowledge about the sophisticated interactions and effects between lncRNAs and genome, hence the lncRNAs implication for overcoming the drug resistance in glioblastoma needs more in-depth research. In addition, as mentioned in some studies, silencing the particular lncRNAs may be an effective strategy to reverse the drug resistance in glioblastoma. Therefore, targeting and delivering strategies such as using nanoparticles and extracellular vesicles in carrying lncRNA (exosomes) for lncRNAs is another issue that needs to be addressed urgently.

In addition to treatment, the gene expression analysis and reporting the differential gene expression profile of glioblastoma and/or drug resistance glioblastoma samples compared to normal tissues can help to manage both drug-sensitive and drug-resistant forms of this disease.

Author Contributions: Conceptualization, B.M., B.B. and W.C.; investigation, P.M. and B.B.; resources, B.M. and W.C.; writing-original draft preparation, P.M. and F.V.; writing—review and editing, S.D., B.B., B.M., W.C.; visualization, B.M. and W.C.; supervision, B.M. and W.C.; project administration, B.M. and W.C. All authors have read and agreed to the published version of the manuscript.

Institutional Review Board Statement: Not applicable.

Informed Consent Statement: Not applicable.

Data Availability Statement: Data sharing not applicable.

Conflicts of Interest: The authors declare no conflict of interest. 


\section{References}

1. Whitehead, C.A.; Kaye, A.H.; Drummond, K.J.; Widodo, S.S.; Mantamadiotis, T.; Vella, L.J.; Stylli, S.S. Extracellular vesicles and their role in glioblastoma. Crit. Rev. Clin. Lab. Sci. 2020, 57, 227-252. [CrossRef] [PubMed]

2. Ferris, S.P.; Hofmann, J.W.; Solomon, D.A.; Perry, A. Characterization of gliomas: From morphology to molecules. Virchows Arch. 2017, 471, 257-269. [CrossRef] [PubMed]

3. Komori, T.; Muragaki, Y.; Chernov, M.F. Pathology and genetics of gliomas. In Intracranial Gliomas Part II-Adjuvant Therapy; Karger Publishers: Berlin, Germania, 2018; Volume 31, pp. 1-37.

4. Jackson, C.M.; Choi, J.; Lim, M. Mechanisms of immunotherapy resistance: Lessons from glioblastoma. Nat. Immunol. 2019, 20, 1100-1109. [CrossRef]

5. Grech, N.; Dalli, T.; Mizzi, S.; Meilak, L.; Calleja, N.; Zrinzo, A. Rising incidence of glioblastoma multiforme in a well-defined population. Cureus 2020, 12, e8195. [CrossRef]

6. Le Rhun, E.; Preusser, M.; Roth, P.; Reardon, D.A.; van den Bent, M.; Wen, P.; Reifenberger, G.; Weller, M. Molecular targeted therapy of glioblastoma. Cancer Treat. Rev. 2019, 80, 101896. [CrossRef]

7. Oliver, L.; Lalier, L.; Salaud, C.; Heymann, D.; Cartron, P.F.; Vallette, F. Drug resistance in glioblastoma: Are persisters the key to therapy? Cancer Drug Resist. 2020, 3, 1-15. [CrossRef]

8. Zahreddine, H.; Borden, K.L. Mechanisms and insights into drug resistance in cancer. Front. Pharmacol. 2013, 4, 28. [CrossRef]

9. Sampath, D.; Cortes, J.; Estrov, Z.; Du, M.; Shi, Z.; Andreeff, M.; Gandhi, V.; Plunkett, W. Pharmacodynamics of cytarabine alone and in combination with 7-hydroxystaurosporine (ucn-01) in aml blasts in vitro and during a clinical trial. Blood 2006, 107, 2517-2524. [CrossRef] [PubMed]

10. Vasan, N.; Baselga, J.; Hyman, D.M. A view on drug resistance in cancer. Nature 2019, 575, 299-309. [CrossRef]

11. Mansoori, B.; Mohammadi, A.; Davudian, S.; Shirjang, S.; Baradaran, B. The different mechanisms of cancer drug resistance: A brief review. Adv. Pharm. Bull. 2017, 7, 339-348. [CrossRef] [PubMed]

12. Ghasabi, M.; Mansoori, B.; Mohammadi, A.; Duijf, P.H.; Shomali, N.; Shirafkan, N.; Mokhtarzadeh, A.; Baradaran, B. Micrornas in cancer drug resistance: Basic evidence and clinical applications. J. Cell. Physiol. 2019, 234, 2152-2168. [CrossRef]

13. Naghizadeh, S.; Mansoori, B.; Mohammadi, A.; Sakhinia, E.; Baradaran, B. Gene silencing strategies in cancer therapy: An update for drug resistance. Curr. Med. Chem. 2019, 26, 6282-6303. [CrossRef]

14. Yousefi, H.; Maheronnaghsh, M.; Molaei, F.; Mashouri, L.; Aref, A.R.; Momeny, M.; Alahari, S.K. Long noncoding rnas and exosomal lncrnas: Classification, and mechanisms in breast cancer metastasis and drug resistance. Oncogene 2019, $39,1-22$. [CrossRef] [PubMed]

15. Fang, Y.; Fullwood, M.J. Roles, functions, and mechanisms of long non-coding rnas in cancer. Genom. Proteom. Bioinform. 2016, 14, 42-54. [CrossRef] [PubMed]

16. Wang, J.; Yang, S.; Ji, Q.; Li, Q.; Zhou, F.; Li, Y.; Yuan, F.; Liu, J.; Tian, Y.; Zhao, Y. Long non-coding rna epic1 promotes cell proliferation and motility and drug resistance in glioma. Mol. Ther. Oncolytics 2020, 17, 130-137. [CrossRef]

17. Naderi-Meshkin, H.; Lai, X.; Amirkhah, R.; Vera, J.; Rasko, J.E.; Schmitz, U. Exosomal lncrnas and cancer: Connecting the missing links. Bioinformatics 2019, 35, 352-360. [CrossRef] [PubMed]

18. Liu, S.; Mitra, R.; Zhao, M.-M.; Fan, W.; Eischen, C.M.; Yin, F.; Zhao, Z. The potential roles of long noncoding rnas (lncrna) in glioblastoma development. Mol. Cancer Ther. 2016, 15, 2977-2986. [CrossRef] [PubMed]

19. Prensner, J.R.; Chinnaiyan, A.M. The emergence of lncrnas in cancer biology. Cancer Discov. 2011, 1, 391-407. [CrossRef]

20. Liz, J.; Esteller, M. Lncrnas and micrornas with a role in cancer development. Biochim. Biophys. Acta Gene Regul. Mech. 2016, 1859, 169-176. [CrossRef] [PubMed]

21. Huarte, M. The emerging role of lncrnas in cancer. Nat. Med. 2015, 21, 1253-1261. [CrossRef] [PubMed]

22. Evans, J.R.; Feng, F.Y.; Chinnaiyan, A.M. The bright side of dark matter: Lncrnas in cancer. J. Clin. Investig. 2016, 126, 2775-2782. [CrossRef]

23. Castro-Oropeza, R.; Melendez-Zajgla, J.; Maldonado, V.; Vazquez-Santillan, K. The emerging role of lncrnas in the regulation of cancer stem cells. Cell. Oncol. 2018, 41, 585-603. [CrossRef] [PubMed]

24. Zhang, R.; Xia, L.Q.; Lu, W.W.; Zhang, J.; Zhu, J.S. Lncrnas and cancer. Oncol. Lett. 2016, 12, 1233-1239. [CrossRef] [PubMed]

25. Li, J.; Tian, H.; Yang, J.; Gong, Z. Long noncoding rnas regulate cell growth, proliferation, and apoptosis. DNA Cell Biol. 2016, 35, 459-470. [CrossRef]

26. Wang, K.C.; Chang, H.Y. Molecular mechanisms of long noncoding rnas. Mol. Cell 2011, 43, 904-914. [CrossRef] [PubMed]

27. Perry, R.B.-T.; Ulitsky, I. The functions of long noncoding rnas in development and stem cells. J. Dev. 2016, 143, 3882-3894. [CrossRef]

28. Zhao, Y.; Wang, H.; Wu, C.; Yan, M.; Wu, H.; Wang, J.; Yang, X.; Shao, Q. Construction and investigation of lncrna-associated cerna regulatory network in papillary thyroid cancer. Oncol. Rep. 2018, 39, 1197-1206. [CrossRef] [PubMed]

29. Barry, G. Integrating the roles of long and small non-coding rna in brain function and disease. Mol. Psychiatry 2014, 19, 410-416. [CrossRef]

30. Nitsche, A. Tracing the evolution of long non-coding RNAs; University of Leipzig; 2017.

31. Yu, B.; Wang, S. Angio-lncrs: Lncrnas that regulate angiogenesis and vascular disease. Theranostics 2018, 8, 3654. [CrossRef] 
32. Xiao, J.-H.; Hao, Q.-Y.; Wang, K.; Paul, J.; Wang, Y.-X. Emerging role of micrornas and long noncoding rnas in healthy and diseased lung. In Pulmonary Vasculature Redox Signaling in Health and Disease; Springer: Berlin/Heidelberg, Germany, 2017; pp. 343-359.

33. Iyer, M.K.; Niknafs, Y.S.; Malik, R.; Singhal, U.; Sahu, A.; Hosono, Y.; Barrette, T.R.; Prensner, J.R.; Evans, J.R.; Zhao, S. The landscape of long noncoding rnas in the human transcriptome. Nat. Genet. 2015, 47, 199-208. [CrossRef]

34. Chen, H.; Shan, G. The physiological function of long-noncoding rnas. Non-Coding Rna Res. 2020, 5, 178-184. [CrossRef] [PubMed]

35. Li, L.; Chang, H.Y. Physiological roles of long noncoding rnas: Insight from knockout mice. Trends Cell Biol. 2014, 24, 594-602. [CrossRef]

36. Fernandes, J.C.; Acuña, S.M.; Aoki, J.I.; Floeter-Winter, L.M.; Muxel, S.M. Long non-coding rnas in the regulation of gene expression: Physiology and disease. J. Non-Coding Rna 2019, 5, 17. [CrossRef]

37. Schmitt, A.M.; Chang, H.Y. Long noncoding rnas in cancer pathways. Cancer Cell 2016, 29, 452-463. [CrossRef] [PubMed]

38. Rasool, M.; Malik, A.; Zahid, S.; Ashraf, M.A.B.; Qazi, M.H.; Asif, M.; Zaheer, A.; Arshad, M.; Raza, A.; Jamal, M.S. Non-coding rnas in cancer diagnosis and therapy. Non-Coding Rna Res. 2016, 1, 69-76. [CrossRef]

39. Niland, C.; Merry, C.; Khalil, A. Emerging roles for long non-coding rnas in cancer and neurological disorders. Front. Genet. 2012, 3, 25. [CrossRef]

40. Bolha, L.; Ravnik-Glavač, M.; Glavač, D. Long noncoding rnas as biomarkers in cancer. Dis. Markers 2017, 2017. [CrossRef]

41. Zeng, H.; Xu, N.; Liu, Y.; Liu, B.; Yang, Z.; Fu, Z.; Lian, C.; Guo, H. Genomic profiling of long non-coding rna and mrna expression associated with acquired temozolomide resistance in glioblastoma cells. Int. J. Oncol. 2017, 51, 445-455. [CrossRef] [PubMed]

42. Bhan, A.; Soleimani, M.; Mandal, S.S. Long noncoding rna and cancer: A new paradigm. Cancer Res. 2017, 77, 3965-3981. [CrossRef]

43. Bartonicek, N.; Maag, J.L.; Dinger, M.E. Long noncoding rnas in cancer: Mechanisms of action and technological advancements. Mol. Cancer 2016, 15, 1-10. [CrossRef]

44. Zha, L.; Wang, Z.; Tang, W.; Zhang, N.; Liao, G.; Huang, Z. Genome-wide analysis of hmga2 transcription factor binding sites by chip on chip in gastric carcinoma cells. Mol. Cell. Biochem. 2012, 364, 243-251. [CrossRef]

45. Zhang, X.; Sun, S.; Pu, J.K.S.; Tsang, A.C.O.; Lee, D.; Man, V.O.Y.; Lui, W.M.; Wong, S.T.S.; Leung, G.K.K. Long non-coding rna expression profiles predict clinical phenotypes in glioma. Neurobiol. Dis. 2012, 48, 1-8. [CrossRef] [PubMed]

46. Murat, A.; Migliavacca, E.; Gorlia, T.; Lambiv, W.L.; Shay, T.; Hamou, M.-F.; De Tribolet, N.; Regli, L.; Wick, W.; Kouwenhoven, M.C. Stem cell-related "self-renewal" signature and high epidermal growth factor receptor expression associated with resistance to concomitant chemoradiotherapy in glioblastoma. J. Clin. Oncol. 2008, 26, 3015-3024. [CrossRef] [PubMed]

47. Zhang, X.-Q.; Leung, G.K.-K. Long non-coding rnas in glioma: Functional roles and clinical perspectives. Neurochem. Int. 2014, 77, 78-85. [CrossRef] [PubMed]

48. Grzmil, M.; Morin, P.; Lino, M.M.; Merlo, A.; Frank, S.; Wang, Y.; Moncayo, G.; Hemmings, B.A. Map kinase-interacting kinase 1 regulates smad2-dependent tgf- $\beta$ signaling pathway in human glioblastoma. Cancer Res. 2011, 71, 2392-2402. [CrossRef] [PubMed]

49. Li, Q.; Jia, H.; Li, H.; Dong, C.; Wang, Y.; Zou, Z. Lncrna and mrna expression profiles of glioblastoma multiforme (gbm) reveal the potential roles of lncrnas in gbm pathogenesis. Tumor Biol. 2016, 37, 14537-14552. [CrossRef]

50. Wang, W.; Yang, F.; Zhang, L.; Chen, J.; Zhao, Z.; Wang, H.; Wu, F.; Liang, T.; Yan, X.; Li, J. Lncrna profile study reveals four-lncrna signature associated with the prognosis of patients with anaplastic gliomas. Oncotarget 2016, 7, 77225. [CrossRef]

51. Saenz-Antoñanzas, A.; Auzmendi-Iriarte, J.; Carrasco-Garcia, E.; Moreno-Cugnon, L.; Ruiz, I.; Villanua, J.; Egaña, L.; Otaegui, D.; Samprón, N.; Matheu, A. Liquid biopsy in glioblastoma: Opportunities, applications and challenges. Cancers 2019, 11, 950. [CrossRef]

52. Tan, S.K.; Pastori, C.; Penas, C.; Komotar, R.J.; Ivan, M.E.; Wahlestedt, C.; Ayad, N.G. Serum long noncoding rna hotair as a novel diagnostic and prognostic biomarker in glioblastoma multiforme. Mol. Cancer 2018, 17, 74. [CrossRef]

53. Shen, J.; Hodges, T.R.; Song, R.; Gong, Y.; Calin, G.A.; Heimberger, A.B.; Zhao, H. Serum hotair and gas5 levels as predictors of survival in patients with glioblastoma. Mol. Carcinog. 2018, 57, 137-141. [CrossRef]

54. Vassallo, I.; Zinn, P.; Lai, M.; Rajakannu, P.; Hamou, M.; Hegi, M. Wif1 re-expression in glioblastoma inhibits migration through attenuation of non-canonical wnt signaling by downregulating the lncrna malat1. Oncogene 2016, 35, 12-21. [CrossRef]

55. Han, Y.; Wu, Z.; Wu, T.; Huang, Y.; Cheng, Z.; Li, X.; Sun, T.; Xie, X.; Zhou, Y.; Du, Z. Tumor-suppressive function of long noncoding rna malat1 in glioma cells by downregulation of mmp2 and inactivation of erk/mapk signaling. J. Cell Death 2016, 7, e2123. [CrossRef]

56. Cao, S.; Wang, Y.; Li, J.; Lv, M.; Niu, H.; Tian, Y. Tumor-suppressive function of long noncoding rna malat1 in glioma cells by suppressing mir-155 expression and activating fbxw7 function. Am. J. Cancer Res. 2016, 6, 2561. [PubMed]

57. Ramalho-Carvalho, J.; Graça, I.; Gomez, A.; Oliveira, J.; Henrique, R.; Esteller, M.; Jerónimo, C. Downregulation of mir-130b $301 \mathrm{~b}$ cluster is mediated by aberrant promoter methylation and impairs cellular senescence in prostate cancer. J. Hematol. Oncol. 2017, 10, 1-13. [CrossRef] [PubMed]

58. Fu, Z.; Luo, W.; Wang, J.; Peng, T.; Sun, G.; Shi, J.; Li, Z.; Zhang, B. Malat1 activates autophagy and promotes cell proliferation by sponging mir-101 and upregulating stmn1, rab5a and atg4d expression in glioma. Biochem. Biophys. Res. Commun. 2017, 492, 480-486. [CrossRef] 
59. Xiong, Z.; Wang, L.; Wang, Q.; Yuan, Y. Lnc rna malat 1/mir-129 axis promotes glioma tumorigenesis by targeting sox 2. J. Cell. Mol. Med. 2018, 22, 3929-3940. [CrossRef] [PubMed]

60. Zhang, K.; Sun, X.; Zhou, X.; Han, L.; Chen, L.; Shi, Z.; Zhang, A.; Ye, M.; Wang, Q.; Liu, C. Long non-coding rna hotair promotes glioblastoma cell cycle progression in an ezh2 dependent manner. Oncotarget 2015, 6, 537. [CrossRef]

61. Ke, J.; Yao, Y.-L.; Zheng, J.; Wang, P.; Liu, Y.-H.; Ma, J.; Li, Z.; Liu, X.-B.; Li, Z.-Q.; Wang, Z.-H. Knockdown of long non-coding rna hotair inhibits malignant biological behaviors of human glioma cells via modulation of mir-326. Oncotarget 2015, 6, 21934. [CrossRef] [PubMed]

62. Sa, L.; Li, Y.; Zhao, L.; Liu, Y.; Wang, P.; Liu, L.; Li, Z.; Ma, J.; Cai, H.; Xue, Y. The role of hotair/mir-148b-3p/usf1 on regulating the permeability of btb. Front. Mol. Neurosci. 2017, 10, 194. [CrossRef]

63. Zhang, S.; Zhao, B.S.; Zhou, A.; Lin, K.; Zheng, S.; Lu, Z.; Chen, Y.; Sulman, E.P.; Xie, K.; Bögler, O. M6a demethylase alkbh5 maintains tumorigenicity of glioblastoma stem-like cells by sustaining foxm1 expression and cell proliferation program. Cancer Cell 2017, 31, 591-606. e596. [CrossRef]

64. Xu, L.-M.; Chen, L.; Li, F.; Zhang, R.; Li, Z.-y.; Chen, F.-F.; Jiang, X.-D. Over-expression of the long non-coding rna hottip inhibits glioma cell growth by bre. J. Exp. Clin. Cancer Res. 2016, 35, 162. [CrossRef]

65. Zhang, S.; Wang, W.; Liu, G.; Xie, S.; Li, Q.; Li, Y.; Lin, Z. Long non-coding rna hottip promotes hypoxia-induced epithelialmesenchymal transition of malignant glioma by regulating the mir-101/zeb1 axis. Biomed. Pharmacother. 2017, 95, 711-720. [CrossRef]

66. Wang, Q.; Zhang, J.; Liu, Y.; Zhang, W.; Zhou, J.; Duan, R.; Pu, P.; Kang, C.; Han, L. A novel cell cycle-associated lncrna, hoxa11-as, is transcribed from the 5-prime end of the hoxa transcript and is a biomarker of progression in glioma. Cancer Lett. 2016, 373, 251-259. [CrossRef] [PubMed]

67. Cui, Y.; Yi, L.; Zhao, J.-Z.; Jiang, Y.-G. Long noncoding rna hoxa11-as functions as mirna sponge to promote the glioma tumorigenesis through targeting mir-140-5p. DNA Cell Biol. 2017, 36, 822-828. [CrossRef] [PubMed]

68. Xu, C.; He, T.; Li, Z.; Liu, H.; Ding, B. Regulation of hoxa11-as/mir-214-3p/ezh2 axis on the growth, migration and invasion of glioma cells. Biomed. Pharmacother. 2017, 95, 1504-1513. [CrossRef]

69. Yang, J.; Liu, B.; Yang, B.; Meng, Q. Long non-coding rna homeobox (hox) a11-as promotes malignant progression of glioma by targeting mir-124-3p. Neoplasma 2018, 65, 505. [PubMed]

70. Deguchi, S.; Katsushima, K.; Hatanaka, A.; Shinjo, K.; Ohka, F.; Wakabayashi, T.; Zong, H.; Natsume, A.; Kondo, Y. Oncogenic effects of evolutionarily conserved noncoding rna econexin on gliomagenesis. Oncogene 2017, 36, 4629-4640. [CrossRef]

71. Zhao, X.; Wang, P.; Liu, J.; Zheng, J.; Liu, Y.; Chen, J.; Xue, Y. Gas5 exerts tumor-suppressive functions in human glioma cells by targeting mir-222. Mol. Ther. Oncolytics 2015, 23, 1899-1911. [CrossRef]

72. Li, X.; Zhou, Y.; Li, Y.; Yang, L.; Ma, Y.; Peng, X.; Yang, S.; Liu, J.; Li, H. Autophagy: A novel mechanism of chemoresistance in cancers. Biomed. Pharmacother. 2019, 119, 109415. [CrossRef]

73. Jiang, X.; Yan, Y.; Hu, M.; Chen, X.; Wang, Y.; Dai, Y.; Wu, D.; Wang, Y.; Zhuang, Z.; Xia, H. Increased level of h19 long noncoding rna promotes invasion, angiogenesis, and stemness of glioblastoma cells. J. Neurosurg. 2016, 124, 129-136. [CrossRef]

74. Li, W.; Jiang, P.; Sun, X.; Xu, S.; Ma, X.; Zhan, R. Suppressing h19 modulates tumorigenicity and stemness in u251 and u87mg glioma cells. Cell. Mol. Neurobiol. 2016, 36, 1219-1227. [CrossRef]

75. Shi, Y.; Wang, Y.; Luan, W.; Wang, P.; Tao, T.; Zhang, J.; Qian, J.; Liu, N.; You, Y. Long non-coding rna h19 promotes glioma cell invasion by deriving mir-675. PLoS ONE 2014, 9, e86295. [CrossRef]

76. Jia, P.; Cai, H.; Liu, X.; Chen, J.; Ma, J.; Wang, P.; Liu, Y.; Zheng, J.; Xue, Y. Long non-coding rna h19 regulates glioma angiogenesis and the biological behavior of glioma-associated endothelial cells by inhibiting microrna-29a. Cancer Lett. 2016, 381, 359-369. [CrossRef] [PubMed]

77. Zhao, H.; Peng, R.; Liu, Q.; Liu, D.; Du, P.; Yuan, J.; Peng, G.; Liao, Y. The lncrna h19 interacts with mir-140 to modulate glioma growth by targeting iaspp. Arch. Biochem. Biophys. 2016, 610, 1-7. [CrossRef] [PubMed]

78. Chen, L.; Wang, Y.; He, J.; Zhang, C.; Chen, J.; Shi, D. Long noncoding rna h19 promotes proliferation and invasion in human glioma cells by downregulating mir-152. Oncol. Res. Featur. Preclin. Clin. Cancer Ther. 2018, 26, 1419-1428. [CrossRef]

79. Yao, Y.; Ma, J.; Xue, Y.; Wang, P.; Li, Z.; Liu, J.; Chen, L.; Xi, Z.; Teng, H.; Wang, Z. Knockdown of long non-coding rna xist exerts tumor-suppressive functions in human glioblastoma stem cells by up-regulating mir-152. Cancer Lett. 2015, 359, 75-86. [CrossRef] [PubMed]

80. Wang, Z.; Yuan, J.; Li, L.; Yang, Y.; Xu, X.; Wang, Y. Long non-coding rna xist exerts oncogenic functions in human glioma by targeting mir-137. Am. J. Transl. Res. 2017, 9, 1845.

81. Cheng, Z.; Li, Z.; Ma, K.; Li, X.; Tian, N.; Duan, J.; Xiao, X.; Wang, Y. Long non-coding rna xist promotes glioma tumorigenicity and angiogenesis by acting as a molecular sponge of mir-429. J. Cancer 2017, 8, 4106. [CrossRef]

82. Wang, Y.; Wang, Y.; Li, J.; Zhang, Y.; Yin, H.; Han, B. Crnde, a long-noncoding rna, promotes glioma cell growth and invasion through mtor signaling. Cancer Lett. 2015, 367, 122-128. [CrossRef]

83. Zheng, J.; Liu, X.; Wang, P.; Xue, Y.; Ma, J.; Qu, C.; Liu, Y. Crnde promotes malignant progression of glioma by attenuating mir-384/piwil4/stat3 axis. Mol. Ther. 2016, 24, 1199-1215. [CrossRef]

84. Li, D.-X.; Fei, X.-R.; Dong, Y.-F.; Cheng, C.-D.; Yang, Y.; Deng, X.-F.; Huang, H.-L.; Niu, W.-X.; Zhou, C.-X.; Xia, C.-Y. The long non-coding rna crnde acts as a cerna and promotes glioma malignancy by preventing mir-136-5p-mediated downregulation of bcl-2 and wnt2. Oncotarget 2017, 8, 88163. [CrossRef] 
85. Chen, Q.; Cai, J.; Wang, Q.; Wang, Y.; Liu, M.; Yang, J.; Zhou, J.; Kang, C.; Li, M.; Jiang, C. Long noncoding rna neat1, regulated by the egfr pathway, contributes to glioblastoma progression through the wnt/ $\beta$-catenin pathway by scaffolding ezh2. Clin. Cancer Res. 2018, 24, 684-695. [CrossRef] [PubMed]

86. Zhen, L.; Yun-hui, L.; Hong-yu, D.; Jun, M.; Yi-long, Y. Long noncoding rna neat1 promotes glioma pathogenesis by regulating mir-449b-5p/c-met axis. Tumor Biol. 2016, 37, 673-683. [CrossRef]

87. Gong, W.; Zheng, J.; Liu, X.; Ma, J.; Liu, Y.; Xue, Y. Knockdown of neat1 restrained the malignant progression of glioma stem cells by activating microrna let-7e. Oncotarget 2016, 7, 62208. [CrossRef] [PubMed]

88. Yang, X.; Xiao, Z.; Du, X.; Huang, L.; Du, G. Silencing of the long non-coding rna neat1 suppresses glioma stem-like properties through modulation of the mir-107/cdk6 pathway. Oncol. Rep. 2017, 37, 555-562. [CrossRef] [PubMed]

89. Zhou, K.; Zhang, C.; Yao, H.; Zhang, X.; Zhou, Y.; Che, Y.; Huang, Y. Knockdown of long non-coding rna neat1 inhibits glioma cell migration and invasion via modulation of sox2 targeted by mir-132. Mol. Cancer 2018, 17, 105. [CrossRef] [PubMed]

90. Guo, J.; Cai, H.; Zheng, J.; Liu, X.; Liu, Y.; Ma, J.; Que, Z.; Gong, W.; Gao, Y.; Tao, W. Long non-coding rna neat1 regulates permeability of the blood-tumor barrier via mir-181d-5p-mediated expression changes in zo-1, occludin, and claudin-5. Biochim. Biophys. Acta Mol. Basis Dis. 2017, 1863, 2240-2254. [CrossRef]

91. Teng, H.; Wang, P.; Xue, Y.; Liu, X.; Ma, J.; Cai, H.; Xi, Z.; Li, Z.; Liu, Y. Role of hcp5-mir-139-runx1 feedback loop in regulating malignant behavior of glioma cells. Mol. Ther. 2016, 24, 1806-1822. [CrossRef]

92. Mineo, M.; Ricklefs, F.; Rooj, A.K.; Lyons, S.M.; Ivanov, P.; Ansari, K.I.; Nakano, I.; Chiocca, E.A.; Godlewski, J.; Bronisz, A. The long non-coding rna hif1a-as2 facilitates the maintenance of mesenchymal glioblastoma stem-like cells in hypoxic niches. Cell Rep. 2016, 15, 2500-2509. [CrossRef]

93. Guo, H.; Wu, L.; Yang, Q.; Ye, M.; Zhu, X. Functional linc-pou3f3 is overexpressed and contributes to tumorigenesis in glioma. Gene 2015, 554, 114-119. [CrossRef]

94. Wang, P.; Liu, Y.-H.; Yao, Y.-L.; Li, Z.; Li, Z.-Q.; Ma, J.; Xue, Y.-X. Long non-coding rna casc2 suppresses malignancy in human gliomas by mir-21. Cell. Signal. 2015, 27, 275-282. [CrossRef]

95. Li, J.; Ji, X.; Wang, H. Targeting long noncoding rna hmmr-as1 suppresses and radiosensitizes glioblastoma. Neoplasia 2018, 20, 456-466. [CrossRef]

96. Zhang, S.; Guo, W. Long non-coding rna meg3 suppresses the growth of glioma cells by regulating the mir-96-5p/mtss 1 signaling pathway. Mol. Med. Rep. 2019, 20, 4215-4225. [CrossRef] [PubMed]

97. Gao, W.; Li, H.; Liu, Y.; Zhang, Y.; Zhao, H.; Liu, F. Long non-coding rna flvcr1-as1 promotes glioma cell proliferation and invasion by negatively regulating mir-30b-3p. Mol. Med. Rep. 2020, 22, 723-732. [CrossRef]

98. Li, C.; Zheng, H.; Hou, W.; Bao, H.; Xiong, J.; Che, W.; Gu, Y.; Sun, H.; Liang, P. Long non-coding rna linc00645 promotes tgf- $\beta$-induced epithelial-mesenchymal transition by regulating mir-205-3p-zeb1 axis in glioma. Cell Death Dis. 2019, 10, 1-17. [CrossRef]

99. Han, M.; Wang, S.; Fritah, S.; Wang, X.; Zhou, W.; Yang, N.; Ni, S.; Huang, B.; Chen, A.; Li, G. Interfering with long non-coding rna mir22hg processing inhibits glioblastoma progression through suppression of wnt/ $\beta$-catenin signalling. Brain 2020, 143, 512-530. [CrossRef] [PubMed]

100. Zottel, A.; Šamec, N.; Videtič Paska, A.; Jovčevska, I. Coding of glioblastoma progression and therapy resistance through long noncoding rnas. Cancers 2020, 12, 1842. [CrossRef] [PubMed]

101. Muscat, A.M.; Wong, N.C.; Drummond, K.J.; Algar, E.M.; Khasraw, M.; Verhaak, R.; Field, K.; Rosenthal, M.A.; Ashley, D.M. The evolutionary pattern of mutations in glioblastoma reveals therapy-mediated selection. Oncotarget 2018, 9, 7844. [CrossRef] [PubMed]

102. Strobel, H.; Baisch, T.; Fitzel, R.; Schilberg, K.; Siegelin, M.D.; Karpel-Massler, G.; Debatin, K.-M.; Westhoff, M.-A. Temozolomide and other alkylating agents in glioblastoma therapy. Biomedicines 2019, 7, 69. [CrossRef]

103. Lee, S.Y. Temozolomide resistance in glioblastoma multiforme. Genes Dis. 2016, 3, 198-210. [CrossRef]

104. Bi, C.-L.; Liu, J.-F.; Zhang, M.-Y.; Lan, S.; Yang, Z.-Y.; Fang, J.-S. Lncrna neat1 promotes malignant phenotypes and tmz resistance in glioblastoma stem cells by regulating let-7g-5p/map3k1 axis. Biosci Rep. 2020, 40, BSR20201111. [CrossRef]

105. Van Meir, E.G.; Hadjipanayis, C.G.; Norden, A.D.; Shu, H.K.; Wen, P.Y.; Olson, J.J. Exciting new advances in neuro-oncology: The avenue to a cure for malignant glioma. CA Cancer J. Clin. 2010, 60, 166-193. [CrossRef]

106. Zhao, C.; Gao, Y.; Guo, R.; Li, H.; Yang, B. Microarray expression profiles and bioinformatics analysis of mrnas, lncrnas, and circrnas in the secondary temozolomide-resistant glioblastoma. Investig. New Drugs 2019, 8, 1-9. [CrossRef]

107. Fritah, S.; Muller, A.; Jiang, W.; Mitra, R.; Sarmini, M.; Dieterle, M.; Golebiewska, A.; Ye, T.; Van Dyck, E.; Herold-Mende, C. Temozolomide-induced rna interactome uncovers novel lncrna regulatory loops in glioblastoma. Cancers 2020, $12,2583$. [CrossRef] [PubMed]

108. Chen, W.; Xu, X.-K.; Li, J.-L.; Kong, K.-K.; Li, H.; Chen, C.; He, J.; Wang, F.; Li, P.; Ge, X.-S. Malat1 is a prognostic factor in glioblastoma multiforme and induces chemoresistance to temozolomide through suppressing mir-203 and promoting thymidylate synthase expression. Oncotarget 2017, 8, 22783. [CrossRef] [PubMed]

109. Li, H.; Yuan, X.; Yan, D.; Li, D.; Guan, F.; Dong, Y.; Wang, H.; Liu, X.; Yang, B. Long non-coding rna malat1 decreases the sensitivity of resistant glioblastoma cell lines to temozolomide. Cell. Physiol. Biochem. 2017, 42, 1192-1201. [CrossRef] [PubMed]

110. Cai, T.; Liu, Y.; Xiao, J. Long noncoding rna malat 1 knockdown reverses chemoresistance to temozolomide via promoting micro rna-101 in glioblastoma. Cancer Med. 2018, 7, 1404-1415. [CrossRef] 
111. Kim, S.-S.; Harford, J.B.; Moghe, M.; Rait, A.; Pirollo, K.F.; Chang, E.H. Targeted nanocomplex carrying sirna against malat1 sensitizes glioblastoma to temozolomide. Nucleic Acids Res. 2018, 46, 1424-1440. [CrossRef]

112. Jia, L.; Tian, Y.; Chen, Y.; Zhang, G. The silencing of lncrna-h19 decreases chemoresistance of human glioma cells to temozolomide by suppressing epithelial-mesenchymal transition via the wnt/ $\beta$-catenin pathway. Oncotargets Ther. 2018, 11, 313. [CrossRef] [PubMed]

113. Jiang, P.; Wang, P.; Sun, X.; Yuan, Z.; Zhan, R.; Ma, X.; Li, W. Knockdown of long noncoding rna h19 sensitizes human glioma cells to temozolomide therapy. Oncotargets Ther. 2016, 9, 3501.

114. Duan, S.; Li, M.; Wang, Z.; Wang, L.; Liu, Y. H19 induced by oxidative stress confers temozolomide resistance in human glioma cells via activating nf-kb signaling. Oncotargets Ther. 2018, 11, 6395. [CrossRef] [PubMed]

115. Lu, C.; Wei, Y.; Wang, X.; Zhang, Z.; Yin, J.; Li, W.; Chen, L.; Lyu, X.; Shi, Z.; Yan, W. DNA-methylation-mediated activating of lncrna snhg12 promotes temozolomide resistance in glioblastoma. Mol. Cancer 2020, 19, 28. [CrossRef]

116. Zhang, Z.; Yin, J.; Lu, C.; Wei, Y.; Zeng, A.; You, Y. Exosomal transfer of long non-coding rna sbf2-as1 enhances chemoresistance to temozolomide in glioblastoma. J. Exp. Clin. Cancer Res. 2019, 38, 1-16. [CrossRef]

117. Peng, Y.; Wu, W.; Shang, Z.; Li, W.; Chen, S. Inhibition of lncrna linc00461/mir-216a/aquaporin 4 pathway suppresses cell proliferation, migration, invasion, and chemoresistance in glioma. Open Life Sci. 2020, 15, 532-543. [CrossRef]

118. Ding, J.; Zhang, L.; Chen, S.; Cao, H.; Xu, C.; Wang, X. Lncrna ccat 2 enhanced resistance of glioma cells against chemodrugs by disturbing the normal function of mir-424. Oncotargets Ther. 2020, 13, 1431. [CrossRef] [PubMed]

119. Du, P.; Zhao, H.; Peng, R.; Liu, Q.; Yuan, J.; Peng, G.; Liao, Y. Lncrna-xist interacts with mir-29c to modulate the chemoresistance of glioma cell to tmz through DNA mismatch repair pathway. Biosci. Rep. 2017, 37, BSR20170696. [CrossRef] [PubMed]

120. Chen, M.; Cheng, Y.; Yuan, Z.; Wang, F.; Yang, L.; Zhao, H. Nck1-as1 increases drug resistance of glioma cells to temozolomide by modulating mir-137/trim24. Cancer Biother. Radiopharm. 2020, 35, 101-108. [CrossRef]

121. Xie, Z.; Li, X.; Chen, H.; Zeng, A.; Shi, Y.; Tang, Y. The lncrna-dleu2/mir-186-5p/pdk3 axis promotes the progress of glioma cells. Am. J. Transl. Res. 2019, 11, 4922.

122. Gu, N.; Wang, X.; Di, Z.; Xiong, J.; Ma, Y.; Yan, Y.E.; Qian, Y.; Zhang, Q.; Yu, J. Silencing lncrna foxd2-as1 inhibits proliferation, migration, invasion and drug resistance of drug-resistant glioma cells and promotes their apoptosis via microrna-98-5p/cpeb4 axis. Aging 2019, 11, 10266. [CrossRef]

123. Chen, W.-L.; Chen, H.-J.; Hou, G.-Q.; Zhang, X.-H.; Ge, J.-W. Linc01198 promotes proliferation and temozolomide resistance in a nedd4-1-dependent manner, repressing pten expression in glioma. Aging 2019, 11, 6053. [CrossRef] [PubMed]

124. He, X.; Sheng, J.; Yu, W.; Wang, K.; Zhu, S.; Liu, Q. Lncrna mir155hg promotes temozolomide resistance by activating the wnt/ $\beta$-catenin pathway via binding to ptbp1 in glioma. Cell. Mol. Neurobiol. 2020, 1-14. [CrossRef] [PubMed]

125. Liu, B.; Zhou, J.; Wang, C.; Chi, Y.; Wei, Q.; Fu, Z.; Lian, C.; Huang, Q.; Liao, C.; Yang, Z. Lncrna sox2ot promotes temozolomide resistance by elevating sox2 expression via alkbh5-mediated epigenetic regulation in glioblastoma. Cell Death Dis. 2020, 11, 1-18. [CrossRef]

126. Zhang, J.; Chen, G.; Gao, Y.; Liang, H. Hotair/mir-125 axis-mediated hexokinase 2 expression promotes chemoresistance in human glioblastoma. J. Cell. Mol. Med. 2020, 24, 5707-5717. [CrossRef]

127. Xu, N.; Liu, B.; Lian, C.; Doycheva, D.M.; Fu, Z.; Liu, Y.; Zhou, J.; He, Z.; Yang, Z.; Huang, Q. Long noncoding rna ac003092. 1 promotes temozolomide chemosensitivity through mir-195/tfpi-2 signaling modulation in glioblastoma. Cell Death Dis. 2018, 9, 1-16. [CrossRef]

128. Shang, C.; Tang, W.; Pan, C.; Hu, X.; Hong, Y. Long non-coding rna tusc7 inhibits temozolomide resistance by targeting mir-10a in glioblastoma. Cancer Chemother. Pharmacol. 2018, 81, 671-678. [CrossRef]

129. Baspinar, Y.; Elmaci, I.; Ozpinar, A.; Altinoz, M.A. Long non-coding rna malat1 as a key target in pathogenesis of glioblastoma. Janus faces or achilles' heal? Gene 2020, 739, 144518. [CrossRef]

130. Voce, D.J.; Bernal, G.M.; Wu, L.; Crawley, C.D.; Zhang, W.; Mansour, N.M.; Cahill, K.E.; Szymura, S.J.; Uppal, A.; Raleigh, D.R. Temozolomide treatment induces lncrna malat1 in an $\mathrm{nf}-\mathrm{kb}$ and $\mathrm{p} 53$ codependent manner in glioblastoma. Cancer Res. 2019, 79, 2536-2548. [CrossRef] [PubMed]

131. Ghafouri-Fard, S.; Esmaeili, M.; Taheri, M. H19 lncrna: Roles in tumorigenesis. Biomed. Pharmacother. 2020, 123, 109774. [CrossRef] [PubMed]

132. Yan, Y.; Xu, Z.; Chen, X.; Wang, X.; Zeng, S.; Zhao, Z.; Qian, L.; Li, Z.; Wei, J.; Huo, L. Novel function of lncrna adamts9-as2 in promoting temozolomide resistance in glioblastoma via upregulating the fus $/ \mathrm{mdm} 2$ ubiquitination axis. Front. Cell Dev. Biol. 2019, 7, 217. [CrossRef] [PubMed]

133. Shangguan, W.; Lv, X.; Tian, N. Foxd2-as1 is a prognostic factor in glioma and promotes temozolomide resistance in a o6methylguanine-DNA methyltransferase-dependent manner. Korean J. Physiol. Pharmacol. 2019, 23, 475-482. [CrossRef] [PubMed]

134. Xu, K.-L.; Xu, Q.-S.; Wu, Z.-X.; Xu, S.-J.; Shen, J. Lncrna neat1 is involved in temozolomide resistance by regulating mgmt in glioblastoma multiforme. Clin. Surg. Res. Commun. 2018, 2, 24-30. [CrossRef] 